\title{
Intraparty and Interparty Variations of Issue Salience in Southern Parties
}

\author{
Shannon L. Bridgmon
}

Political parties have many purposes, but their primary goal is to capture elected office (Aldrich 1995). They also serve as quasi-public organizations that mobilize the electorate and organize political debate. Previous research (Budge and Farlie 1977, 1983; Petrocik 1981, 1996) suggests that parties will emphasize issues that provide them an electoral or policy advantage. However, little exists to determine if this pattern extends to state and regional politics. This study measures the levels of importance southern political parties attach to various issues, as expressed through each state party's platform. State party platforms of southern states in effect during 2009 will serve as the data for this study. After determining levels of issue salience variations among and within southern states, this study confirms that parties emphasize issues to maximize electoral prospects.

\section{Previous Research}

\section{Issue Salience}

Party preferences may certainly be expressed through ideological positions on political issues. Preferences may not be limited to ideology, though. Choices parties make on whether or not to emphasize or downplay certain issues also reflect party preferences. Issue salience refers to the level of importance a party places on a particular policy or social problem. Thus, ideological similarities or differences between parties may not register if their issue agendas differ in content.

Levels of issue salience are not static, though. Dominant issues and social problems change over time, even as citizens and parties are attentive to multiple issues (Nie et al. 1976). Issues may be salient as a result of current social or economic events or parties' responses to the issues (issue framing).

Issues may not be equally salient between voters, parties, and candidates. However, a general pattern of issue salience has emerged between these interests. Salience is determined by which issues reinforce the links between voters and electoral choices. Two approaches toward understanding issue salience are generally accepted, each one emphasizing electoral advantages. Downs (1957) claims political actors actively compete for votes

SHANNON L. BRIDGMON is an assistant professor of political science at the University of Alabama in Huntsville.

The American Review of Politics, Vol. 31, Fall, 2010: 245-275

(C)2010 The American Review of Politics 
within a defined one-dimensional ideological space of political issues. This occurs over a common set of issues on which these actors compete. Another approach for understanding which issues become salient focuses on the emphasis and downplay of issues for electoral advantage. Policy makers will emphasize salient issue they have an electoral advantage on. Likewise, they are motivated to diffuse the salience levels of issues one is electorally weak in. This approach in scholarly literature is referred to as "salience theory" or "issue ownership" (Budge and Farlie 1977; Rabinowitz and Macdonald 1989; Petrocik 1996).

\section{Salience Theory and Issue Ownership}

Budge and Farlie $(1977,1983)$ present a salience theory contending that parties attract a public following constructed on issues that the majority of the electorate supports. Salient issues for a party should be those that provide an electoral advantage to the party. Parties will ignore or discount those issues that benefit their opponents in order to neutralize areas in which the party is electorally weak. Parties typically avoid direct confrontation on issues. Instead, parties will selectively emphasize issues on which the opposition party is electorally weak and seek to deflect those issues where the opposition exhibits strength. Essentially, parties will "talk past" each other on related but not identical issues, ultimately producing two electoral spaces. Budge and Farlie's theory rests on political actors avoiding direct competition rather than competing over a common set of issues as Downs' approach requires. Their examination (1983) of national party platforms in twentythree democracies exhibit selected issue emphases and lack of references to those stressed in opposition party documents.

Rabinowitz and Macdonald (1989) relate a directional theory to salience. Determining which issues to emphasize is a two-step process. As new issues emerge parties first choose which position to adopt. After the party ties itself to that issue it will then decide the level of prominence it will place on that issue. This complements the salience theory as parties determine their electoral (dis)advantage as it relates to a new issue position.

Petrocik $(1981,1996)$ takes the salience theory a step further, asserting that parties "own" certain issue areas. Each party supports positions on issues that project an image of expertise (or greater competence than the opposition party) which the public trusts the party to manage. This ownership is based on the party's overall reputation on an issue and is rooted in two sources. First, the electorate considers the incumbent's (party) record on the issue. The challenging party may use the incumbent party's poor performance in an issue to take control of the "ownership" for that area. This method of issue ownership is based on short-term assessments of the other 
party's handling of the issue. The second basis of the party's reputation relates to the various constituencies of each party. This refers to the various components of a party coalition that remain fairly stable. These constituencies may fall along social characteristics, ethnic, or ideological lines. These constituencies form a link between the issues the party supports and the features of those groups.

Like Rabinowitz and Macdonald (1989), Petrocik (1981) addressed the relationship between new issues, salience, and electoral conditions. How parties respond to emerging issues may also affect intraparty unity as they engage in the directional and salience decisions. According to Petrocik (1981), if a party unit assimilates its focus and position on an issue to an existing issue agenda, then the status quo is maintained. As party units join together and assimilate levels of salience and ideology on an issue, then intraparty unity is strengthened, and vice versa. When the issue agenda changes in content or salience and assimilation is slow or not present, intraparty cleavages are likely to occur. "Unless the new agenda spawns issues that coincide with the concerns of the prevailing issue alignment, cleavages are created within the parties (Petrocik 1981, 111)."

\section{Recent Studies}

Although the theoretical approach toward selected issue emphases emerged three decades ago, there has been renewed interest in testing these ideas in various systems. These studies have largely served to challenge and clarify issue salience/ownership theories.

Some studies have focused on those common sets of issues that do emerge in which both parties must actively engage one another (Sigelman and Buell 2004; Damore 2004; Dellis 2009; Parker 2007). This is known as "issue convergence" (Sigelman and Buell 2004) or "trespassing," which Budge and Farlie (1983) acknowledge must occur at some level among candidates in a normal campaign environment. These issues may emerge as a result of emerging social or economic events, but one of Petrocik's key assertions is that these instances only occur when a candidate is forced to do so.

Sigelman and Buell (2004) do not dismiss Petrocik's assertions that each party may enter a campaign with an electoral advantage over certain issues; however, they find that a condition in which both parties address the same issues - issue convergence-was the norm in U.S. presidential campaigns from 1960-2000, not the exception. Damore (2004) finds that candidates will "trespass" on electorally weak issue space if the issue has become salient for the public, and that Democrats are significantly more likely to trespass on Republican-favored issues than vice versa. 
While some trespassing may be necessary, it may be a proactive strategic campaign tactic. If so, this may further weaken support for salience theory/issue ownership adherents. Dellis (2009) finds that candidates may trespass in order to diffuse an opposition party's ownership of an issue, pointing to President Clinton's cooptation of the welfare reform issue. Likewise, Parker (2007) examines issues dealing with crime, which Petrocik (1996) assigns ownership to the GOP. Parker's analysis of party platforms challenges both Petrocik's ownership assignments and inconsistencies to the theory, as a whole. He writes, "One of the problems of the theory of issue ownership as a theory is specifying what is not consistent with it" (Parker 2007, 26).

Parker also seeks to narrow the scope of issue ownership, suggesting that issue salience/ownership is not directly connected with the general electorate, but rather to specific constituencies, consistent with Pagorelis et al. (2005). Focus on group support is strengthened by Clifton's (2004) examination of the influence of the Christian Coalition on the Republican Party. The subgroup of the Religious Right aids the GOP through voter mobilization, but also through policy expertise that influences official and unofficial party messages. This suggests a recursive systems approach in which parties craft messages to appeal to constituencies, then convert the electoral support of the group into policy influence on issue positions.

\section{Issue Salience in the States}

Beyond national parties, state parties have the freedom to pursue their own policy agendas to respond to their respective political environments. The extent to which an issue is salient within this environment will affect how parties construct the issue agenda (Gimpel and Schuknecht 2003). Jacoby and Schneider (2001) addressed how policy priorities are shaped at the state level. Much of the state policy concerns are determined by public opinion. These preferences are not expressed through individual ideology, but rather through political parties. Policy outputs directed by state parties in governments will reflect the public's priorities. One natural venue for state parties to communicate those priorities is through their platforms.

While public opinion displayed strong effects on policy priorities, Jacoby and Schneider (2001) find that interest groups are the greatest determinant of policy priorities and outputs. Interest groups are most effective in setting priorities if they are few in number and large in size. Under these conditions interest groups may "concentrate" their influence upon establishing priorities and thus, issue salience (consistent with Clifton 2004). Coffey also explored the influence of interest groups on state parties. He surmises that "many interest groups have focused their efforts specifically on state 
parties because they remain important sources of power and are more open to being influenced than the national parties" $(2006,63){ }^{1}$

Thus far, studies indicate how salience may differ between Democrat and Republican parties. However, issue ownership does not address variations in salience within parties, especially at a sub-national level. Little currently exists to determine intraparty variation in issue salience. Libbrecht et al. (2009) find that sub-national parties in Spain that are organizationally fragmented from their national party will embrace a wider range of issue emphases. Thus, greater sub-national party autonomy yields greater intraparty policy variance in salience. Pagorelis et al. (2005) acknowledge that issue salience will vary by region and between sub-national and national party units. However, these examinations were limited to the Spanish and UK systems, respectively. No such literature exists focusing on issue salience in U.S. states.

It is reasonable to assume that each state and national party unit will continue to embrace those issues it has an electoral advantage on and downplay those on which it may be perceived as weak. Thus, state party platforms may seek to discount or overlook issues highlighted in the national platform that the state party may have an electoral weakness on. On the other hand, a state platform may highlight an issue the national platform disregards to protect or enhance an electoral advantage. Both of these choices are consistent with salience theory and Key's (1949) view that parties will distance themselves to enhance electoral benefits.

Many opportunities exist for parties to express their policy preferences. While one dimension of policy preferences involves ideological variance, it ignores non-ideological variations among parties such as salience. While both party units may fundamentally agree in regard to issue position, it may not be clear which issues are the most important to the party. A state party platform may include two statements on Redistribution issues, while another may contain twenty statements. Even though both may yield identical scores, does this reflect a unified party stance on an issue? Not necessarily. The level of issue salience within various party units may also shed light on intraparty unity.

\section{Data and Methods}

The purpose of this study is to determine the level to which southern political parties share a common set of issues on which to state their policy preferences. While understanding the evolution of political issues in the South, this study does not seek to determine the level of change over time. Instead, I assess the current issue environment - a cross-sectional content 
analysis - as expressed through state party platforms to discover the variation of preferences among southern political parties.

\section{Platform as Data Source}

The party platform is a natural starting point in assessing party preferences. It is a major statement of a party's principles and policies, providing us with insight into a state's unique political environment. Historically, the party platform has served as the central medium through which parties present policy alternatives to the voters. Furthermore, the platform is generally the only formal document parties themselves ever issue, serving as the clearest and most authoritatively stated party policy positions (Budge et al. 2001, 6). So, while party agents may issue other sources of policy preferences during a campaign - television ads, newspaper releases and statements, pamphlets, etc. - the platform serves as the only central authoritative statements of the party as a whole. And while individual campaign communications and advertising may reach a wider audience, aimed at the electorate, the platform is also used as a signal to publicists, opinion makers, and campaigns themselves, who in turn craft campaign messages and reinforce the agenda (Budge and Farlie 1983).

Platforms are also a valuable tool in evaluating the level of policymakers' responsiveness to their constituencies. Comparative policy analyses have routinely demonstrated that much legislation passed corresponds to those statements articulated in party platforms (Royed 1996; Rallings 1987; Budge et al. 2001). Pomper (1980, 2003) and Fishel (1985) determined that platforms contain meaningful statements and that platform pledges are frequently fulfilled. This also may extend to the state level, as well (Elling 1979).

Although other indicators of issue agendas have been widely utilized, the platform has several advantages for comparing state agendas. They are accessible for a researcher, they tend to be straightforward in their format, and state platforms are adopted as frequently as their national counterparts, if not more frequently. It is the most comprehensive document detailing the ideology of the party organization itself. Determining the true policy preferences of political actors may be elusive, constantly shifting in response to a dynamic political environment. Official party documents such as a party platform provide the best evidence by which to evaluate the party's preferences (Laver and Garry 2000).

Can state platforms serve as an indicator of state ideology as a whole? According to Ginsberg, "In the absence of survey data, we must infer . . . that the content of these statements is important enough to party leaders to warrant treating changes in the content of party platforms as valid indicators 
of party change" $(1972,607)$. This is consistent with the finding that party executive directors pay particular attention to the contents of the platform and responds to the document for legislative action (Cotter et al. 1984). While examinations of national platforms have routinely served as indicators of policy responsiveness, state party platforms are less frequently used (although not completely ignored). However, recent studies have begun to recognize the utility of state platforms in studying ideology, policy responsiveness, and representation (Paddock 1990, 1992, 1998, 2005; Coffey 2005, 2006; Bridgmon 2009).

The preferences expressed within platform documents are two-fold in nature: (1) those that express ideological preferences on a particular policy issue, as well as (2) the preferences of which policy issues to address (or omit) and the level of emphasis the party places on it. This study assesses the latter aspect of policy preferences. Assessing levels of issue salience serves as a supplemental method to triangulate the subtle differences among party units.

State party platforms vary widely, not only in their content, but also their institutional characteristics. They may differ in terms of drafting process, approach, and frequency. Most states adopt a drafted platform at a regular state party convention, to occur as stated in the state party's bylaws. Not all states have engaged in an elaborate, prescribed routine for adopting a platform or issue agenda. ${ }^{2}$ Furthermore, not every state party drafts an official platform. ${ }^{3}$ Some statements contain general philosophies of the parties, without specific policy endorsements; others use these documents as proxy platforms to enumerate policy positions on a variety of issues.

This study examines the existing platforms in effect in 2009 for both parties of nine southern states. ${ }^{4}$ Both Democrats and Republicans adopt platforms in six of the nine states: Arkansas, Mississippi, North Carolina, South Carolina, Texas, and Virginia. In the remaining three states-Florida, Georgia, and Louisiana - only one of the parties issue authoritative policy documents. ${ }^{5}$ Thus, this study examines fifteen individual southern party platforms, consisting of seven Democratic platforms and eight Republican.

\section{Coding and Measurement}

The primary method for generating data for this study is content analysis. Because of the potential pitfalls of coding bias and errors, several scholars have turned to computer-coded content analysis based on programs utilizing a sort of political dictionary (Laver and Garry 2000; Coffey 2006). These methods should be applauded in terms of attempting to eliminate human error resulting from the subjectivity of hand coding. For this project such programs (Coffey 2006) will not be considered due to potential omis- 
sions of politically significant ideas. Because state platform content is generally marked by brevity in comparison to national platforms, hand coding is appropriate to catch any subtleties and extract such ideas whose context may not be readily interpreted by computer-coding programs. Furthermore, content of platforms may contain phrases or ideas unique to the state that may not coincide with the lexicon of such computer programs and may inadvertently be omitted under such schemas.

Units of analysis vary in conducting content analysis of party platforms. ${ }^{6}$ However, this unit for coding purposes presents some general concerns. Because state platforms will not only vary by content but also by form and length, a smaller unit of analysis for coding is necessary. Thus, if different issues-however short-are addressed within each sentence, there must be adequate coding in order to accurately measure the documents in their entirety.

I have adopted Budge et al.'s (2001) unit of analysis, which is the smallest unit of each policy statement, represented by a complete sentence or a "quasi-sentence." The selected unit is determined by whichever represents the smallest unit of expression of a political idea or issue (Budge et al. 2001, 96). ${ }^{7}$ Ideally, each statement closely reflects the way the party represents itself.

For this discussion, salience is determined by the percentage of policy statements devoted to a domain in relation to the total number of pledges in the platform. Determining levels of individual issues within each domain are calculated by determining the percentage of issue statements related to all statements within the domain. Employing ratios of statements or space to entire sections or the document in its entirety is standard among platform studies (Paddock 1990, 1992, 1998). ${ }^{8}$ Two southern platforms- North Carolina and Louisiana Republicans - do reveal that issue placement matters. While this is not expressly stated, the two platforms are almost identical in style and content. The only substantive difference between the two documents is the order in which the issues are presented.

\section{Issue Classification}

Each platform is divided into general policy areas reflecting a combination of those categorized by Ginsberg (1972), Paddock (1990, 1992), and Budge et al. (2001) in their studies of platforms. This study adopts Laver and Garry (2000) and Budge et al.'s (2001) nomenclature when referring to these categories as "policy domains." Most policy statements will generally be able to be placed within one of these eight domains, though not every statement is coded. Only those offering positions on specific policy issues are considered. Many of these statements will be preceded with the phrase "we support/oppose," "we will (not)," or that the state "should (not)" engage in a 
particular practice. Statements regarding party activities are omitted, unless it is in the context of governing policy. Following Royed (1996), statements of rhetoric and explicit fact are omitted, as well as past policy achievements (or failures). The domains and individual issue areas are summarized as follows:

1. Foreign/Defense: actions concerning relations with foreign states, the international community and national security policy. These two issue areas are separated within this domain based on statements concerning the general use diplomacy as opposed to force, while "foreign" issues include statements regarding positions relating to individual states.

2. Economy: the aggregation of wealth and control over the distribution of wealth by the private sector. Issue areas include role of the public sector/regulations, environment and energy, healthcare, and education.

3. Redistribution: The reallocation of material and economic advantages in favor of the disadvantaged and the provision of a social safety net for vulnerable populations. ${ }^{9}$ Issues include Social Security, social welfare policy in general, and Medicare/Medicaid. ${ }^{10}$

4. Internal Sovereignty: the exercise of the power and increase of the role of the national government with regards to states and localities. This also includes issues of property rights. Statements regarding Native American autonomy or extending statehood to U.S. territories may also be included.

5. Labor \& Industry: workers, including educators, healthcare workers, and veterans; issues involving organized labor and wages, "working poor." This domain also addresses issues of agriculture. ${ }^{11}$

6. Universalism: equality of rights and privileges for minorities and/or women (excludes abortion); also includes issues of civil rights (excluding gay rights), open government and transparency, election reform, disability rights; access to civil courts, "tort reform."

7. Law \& Order/Social Fabric: appeal for control of criminal behavior and administration of criminal justice; war on drugs. Includes homeland security issues; Patriot Act. May also include statements on institutional characteristics of the court system/jurisdiction. Includes gun control/right to bear arms; symbols of American heritage. Includes immigration. May also include ethics (legal constraints, punishments on public officials).

8. Social Issues: The use of coercive power of the state to regulate private behavior based upon traditional societal moral standards. This addresses issues of morality, including religious-based issues: right-to-life (excludes capital punishment), gay rights, stem cell research, prayer in schools, sex education. Also includes issues of parental rights and family life. 


\section{Summary Findings}

Salience levels for each state party platform were calculated at two levels. First, salience was determined for the policy domains as a whole, each one encompassing more than one issue. Next, each domain was subdivided into its respective issue categories, providing a more in-depth analysis. Party domain totals are presented in Table 1.

\section{Economy}

For all southern party platforms, the Economy domain was highly salient. The mean percentage of Economy statements in a platform is 35.6 percent, or more than one-third. This is appropriate given the issue categories classified within the domain - public/private dichotomy and regulation, education, healthcare, and environment/energy policy. These issues, especially issues of education and healthcare, have traditionally been the purview of state policymakers. Likewise state parties will also compete based on an overall position regarding the role of government in society, which is evident in Table 2. The dichotomy between private and public sectors and the overall scope of government tends to emerge as the most salient issue for both parties.

Thus, a high level of salience for the Economy domain is appropriate. This is evident in all Democratic state platforms, where Economy is dominant, with a mean score of 40.7 percent. Economy was most salient for Mississippi and Virginia Democrats, respectively. Economy was least salient for North Carolina Republicans, devoting only 15 percent of its entire platform statements to issues within this domain.

This dominance did not carry over into the GOP. Economy salience levels were tied with Social Issues for Florida Republicans, and were secondary to Social Issues for three GOP platforms-Louisiana, North Carolina, and Texas. Nevertheless, when examining individual issues within the Economy domain, private/public was the most salient issue areas for Republicans. Table 2 reveals only two southern GOP platforms devoted less than 50 percent of the domain statements to this issue. This is largely due to the larger percentage of statements specifically addressing issues of taxation and regulation in these platforms.

Salience levels for other Economy issues reveal variance across states and parties. Education was consistently salient within southern Democratic platforms, representing a mean percentage of 25 percent Economy statements. Every Democratic platform included statements on this issue. This is especially evident for South Carolina Democrats, who devoted 41 percent of Economy statements to the issue. Education was also salient within three 


\begin{tabular}{|c|c|c|c|c|c|c|c|c|c|}
\hline 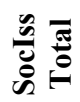 & $\begin{array}{l}\stackrel{0}{0} \dot{0} \\
\dot{\sigma}^{\circ} \\
\dot{\infty}\end{array}$ & $\begin{array}{l}\stackrel{\circ}{\infty} \\
\stackrel{f}{+}\end{array}$ & $\stackrel{\oplus}{\infty}_{\infty}^{\circ}$ & $\stackrel{\circ}{\stackrel{0}{0}}$ & 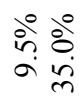 & 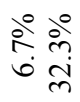 & 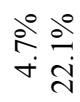 & 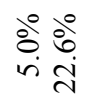 & $\stackrel{\circ}{\circ} \stackrel{\circ}{\circ}$ \\
\hline 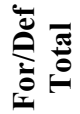 & $\begin{array}{l}\text { ठें } \\
\text { ¿ें }\end{array}$ & o̊ & 守. & ஓं & $\begin{array}{l}80 \\
80 \\
0 \\
0\end{array}$ & $\begin{array}{l}\stackrel{0}{\circ} \stackrel{0}{ } \\
\stackrel{+}{+} \text { in }\end{array}$ & 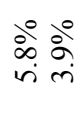 & 仓ัं & 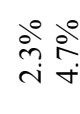 \\
\hline 离 & $\begin{array}{l}\text { ठें } \\
\text { ఏें } \\
=\text { خे }\end{array}$ & 方 & $\begin{array}{l}\stackrel{\circ}{2} \\
\stackrel{2}{a}\end{array}$ & $\begin{array}{l}\stackrel{0}{0} \\
\dot{0} \\
0\end{array}$ & 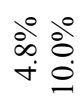 & 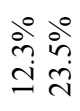 & $\begin{array}{l}\stackrel{0}{\circ} \frac{0}{\check{c}} \\
\stackrel{2}{=}\end{array}$ & $\begin{array}{l}\stackrel{\circ}{\circ} \dot{m}^{\circ} \\
=0\end{array}$ & $\begin{array}{l}\stackrel{0}{\circ} \\
\dot{0} \\
\stackrel{i}{\circ}\end{array}$ \\
\hline 常晋 & 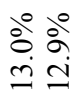 & 官 & $\begin{array}{l}\stackrel{0}{0} \\
\infty \\
\stackrel{0}{0}\end{array}$ & $\stackrel{\circ}{0}_{\infty}^{\circ}$ & 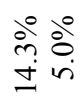 & 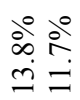 & 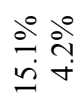 & 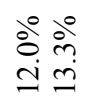 & $\begin{array}{l}\stackrel{0}{\circ} \\
\stackrel{0}{0} \\
\stackrel{0}{0}\end{array}$ \\
\hline 离 & 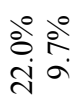 & ठ̊. & $\frac{\partial^{\circ}}{0}$ & $\stackrel{\stackrel{\circ}{n}}{\text { r }}$ & 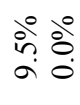 & 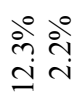 & 官 & 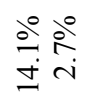 & 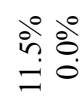 \\
\hline 莞 & $\begin{array}{l}\stackrel{0}{0} \stackrel{0}{i} \\
\dot{b} \\
i\end{array}$ & $\stackrel{0}{0}_{0}^{\circ}$ & $\begin{array}{l}\text { iे } \\
\text { in }\end{array}$ & $\begin{array}{l}\stackrel{0}{\infty} \\
\dot{\sigma}\end{array}$ & $\begin{array}{l}\stackrel{0}{\circ} 80 \\
\text { iे } \\
\dot{J}\end{array}$ & خे & $\begin{array}{l}\text { के } \\
\text { के } \\
\text { in in }\end{array}$ & 華 ัे & बें \\
\hline 总 & $\begin{array}{l}\stackrel{0}{\circ} \\
\dot{0} \\
\dot{0}\end{array}$ & $\begin{array}{l}\stackrel{0}{\infty} \\
\stackrel{j}{f}\end{array}$ & $\begin{array}{l}\stackrel{0}{0} \\
\infty \\
\text { nं }\end{array}$ & तें & 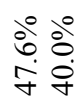 & $\begin{array}{l}\stackrel{2}{\circ} \stackrel{\circ}{+} \\
\stackrel{+}{\forall}\end{array}$ & 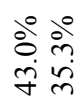 & 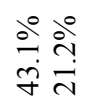 & $\begin{array}{l}\dot{0} \\
\dot{b} \\
\dot{b} \\
\dot{f}\end{array}$ \\
\hline 完 & 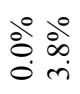 & $\stackrel{\circ}{0}$ & ڤें & ํํㅁ & $\begin{array}{l}0 \\
8 \\
0\end{array}$ & $\stackrel{\partial^{0}}{=} \frac{0}{-\infty}$ & $\begin{array}{l}\partial_{0}^{\circ} \\
\infty \\
\text { in } \\
\text { in }\end{array}$ & ஸें & $\frac{\partial^{\circ}}{\dot{m}} \dot{0}^{\circ}$ \\
\hline Z & $\infty \stackrel{\infty}{\infty}$ & $r$ & $\stackrel{\circ}{\circ}$ & $\cong$ & $\vec{\sim}$ ㅇ & ف유 & 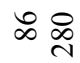 & 令令 & 요 \\
\hline 焉 & $\sum_{\text {II }}$ & రి & $\sum_{\text {至 }}$ & రి & $\sum_{\substack{11 \\
0}}$ & 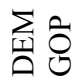 & $\sum_{\substack{1 \\
0}}$ & $\sum_{\text {II }}$ ठ ठ & $\sum_{\substack{1 \\
0}}$ \\
\hline 吾 & 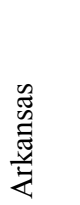 & $\frac{\frac{\pi}{0}}{\frac{0}{0}}$ & $\begin{array}{l}\cdot \frac{\pi}{00} \\
\vdots \\
0 \\
0\end{array}$ & 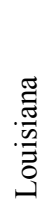 & 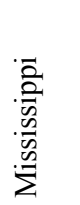 & 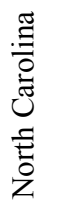 & 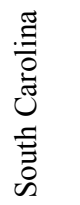 & $\stackrel{\widetilde{\pi}}{\tilde{e}}$ & 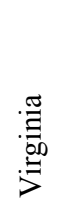 \\
\hline
\end{tabular}




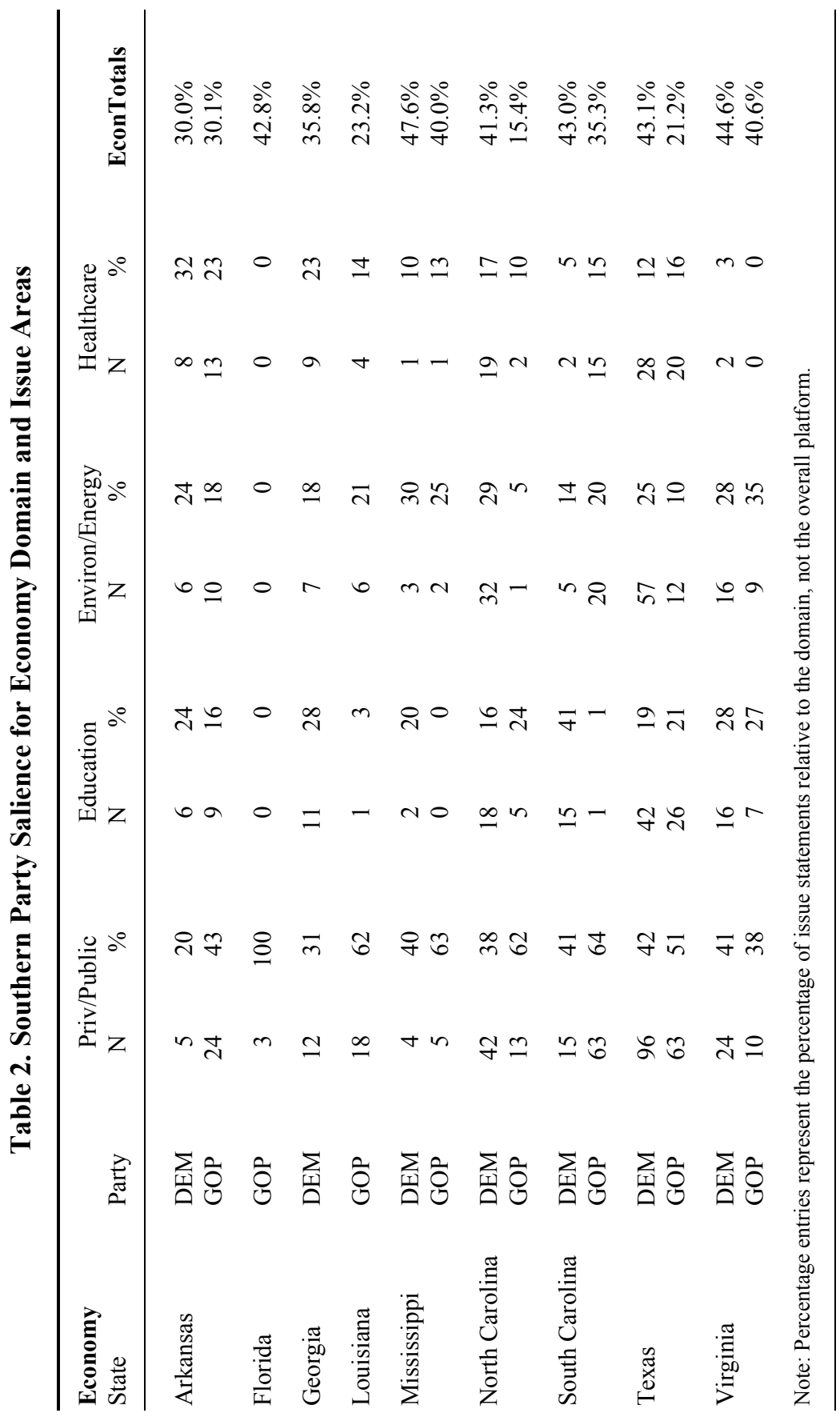


GOP platforms-Texas, North Carolina, and Virginia-with each devoting greater than 20 percent of Economy statements to education.

Environmental and energy policy issues were also salient. This issue area was the most salient for Virginia Republicans (35\%) and Mississippi Democrats $(30 \%)$. Among those platforms including statements on the issue, North Carolina Republicans had the lowest percentage at 5 percent. ${ }^{12}$ The issue of healthcare generally served as the least salient Economy issue, with a mean of 13 percent of domain statements for all platforms. Democrats had a mean issue score of 14.6 percent, while the Republican mean was 11.4 percent. ${ }^{13}$ Within southern platforms, healthcare was the most salient for Arkansas Democrats, devoting 32 percent of their Economy statements to this issue.

\section{Internal Sovereignty}

The domain of Internal Sovereignty was the least salient issue within southern party platforms. This domain represented approximately only 3 percent of all platform statements across the board. Within the domain, issues of local autonomy were dominant (see Table 3). ${ }^{14}$ This is understandable when examining the context of states within the system of federalism. It is natural for parties at the state level to make statements regarding the scope of their authority in relation to the national government. This issue was the most salient for three states that devoted all Internal Sovereignty to this issue-Mississippi and North Carolina Democrats, and Louisiana Republicans. The issue was also highly salient among other GOP platforms (Arkansas, North Carolina, South Carolina, and Texas). This issue also appeared salient for South Carolina and Texas Democrats, as well.

The issue of individual property rights also emerged as salient within several platforms, most notably Virginia Democrats $(75 \%$ of domain statements). South Carolina and Texas Democrats also included statements on the issue, though these three state parties were the only Democrats to comment on the issue. Four Republican platforms addressed property rightsArkansas, North Carolina, South Carolina, and Texas.

\section{Redistribution}

Salience levels for the Redistribution domain varied along party lines. The domain was least salient for Florida Republicans, who issued no statements for the domain. It was most salient for Arkansas Democrats, devoting 16 percent of their platform to issues within the domain. Redistributive issues were almost three times as salient for Democrats ( $8.9 \%$ mean) than for Republican platforms (3\% mean). Within the domain, overall statements 


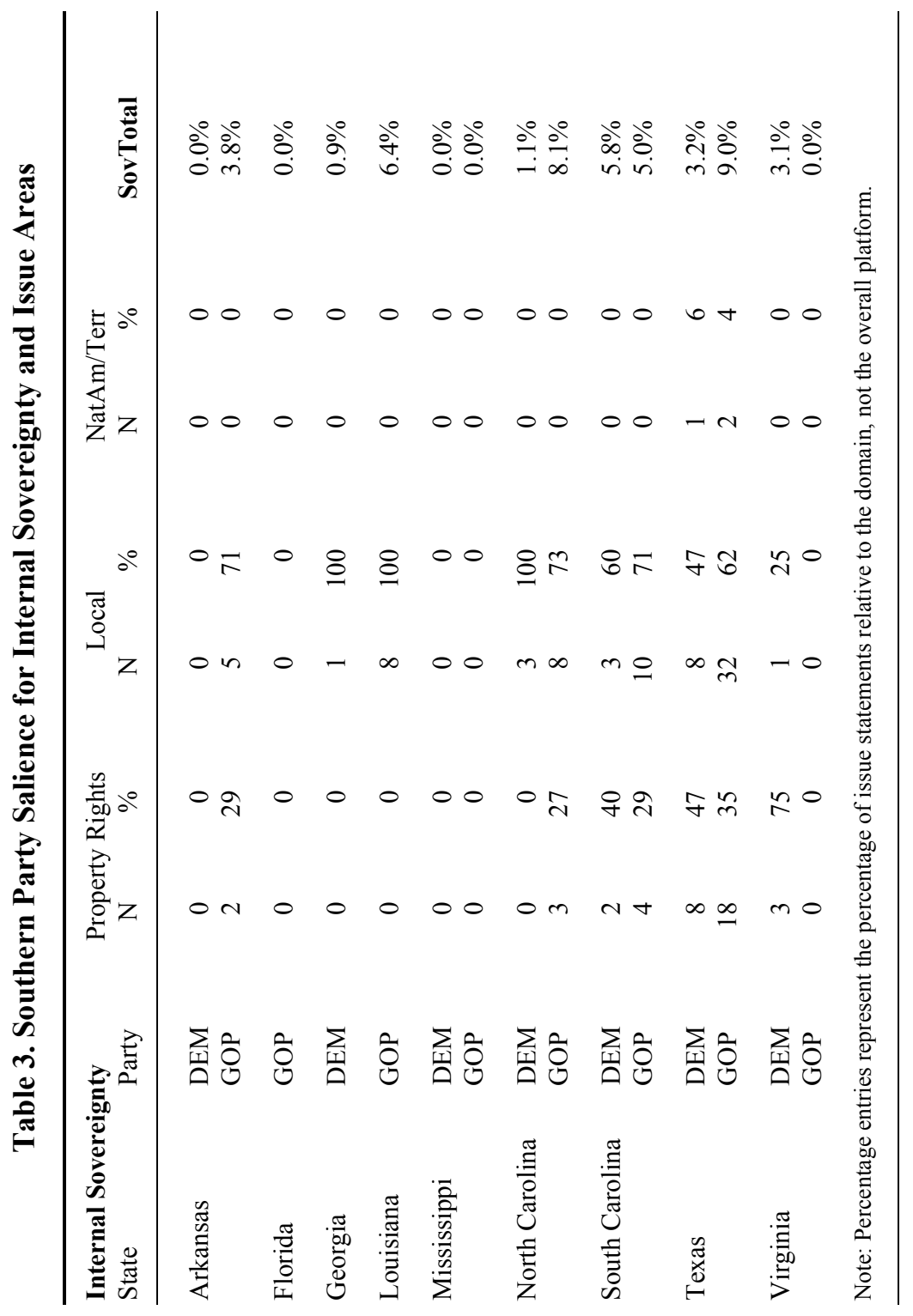


on social welfare/safety net were the most salient, especially for the GOP (see Table 4). Only four GOP platforms made mention of specific welfare issues (Social Security and Medicare/Medicaid). These differences among the issue areas are due to the specificity of statements. GOP statements were generalized statements on the role of the welfare state as a whole, whereas Democratic platforms directed attention to specific welfare and redistributive programs. For instance, only one GOP platform (South Carolina) issued a statement regarding Medicare or Medicaid, while all Democratic platforms except Mississippi Democrats addressed the issue.

Variance of salience levels also emerged within each party. Among Republicans, salience levels ranged from 0 percent (FL) to 5.3 percent (SC). Among Democrats, salience ranged from 5.5 percent (TX and GA) to 16 percent (AR).

\section{Labor \& Industry}

Wide levels of variance emerged within the Labor \& Industry domain, both by party and issue area. The domain was most salient for Arkansas Democrats $(22 \%)$, who devoted more than one in five statements to the domain. It exhibited no salience for Florida and Mississippi Republicans. Democratic platforms yielded 12.7 percent (mean) of their platforms to the domain, while GOP platforms only consisted of 3 percent (mean) Labor \& Industry statements.

Within the domain, salience levels varied among the issue areas. These results are presented in Table 5. Highest levels of salience emerged on issues of labor/union rights and those relating to teachers. Across all platforms, labor issues were the most salient for Arkansas and South Carolina Republicans as well as Georgia, Mississippi, North Carolina, South Carolina, Texas, and Virginia Democrats, respectively. Teacher issues were most salient for Mississippi and North Carolina Republicans, who both devoted all domain statements to this issue. Veterans' issues were most salient for Texas Republicans and Arkansas Democrats, and the issue proved salient on the whole for both parties in the states of Arkansas, South Carolina, and Texas. Agricultural issues proved least salient within the domain, though both parties of Arkansas devoted attention to it and proved to be most salient for South Carolina Republicans.

\section{Universalism}

Salience levels for Universalism as a domain did not vary widely. Mean salience levels for all platforms were approximately 10 percent, with Democratic salience slightly higher than Republicans. Only two platforms- 


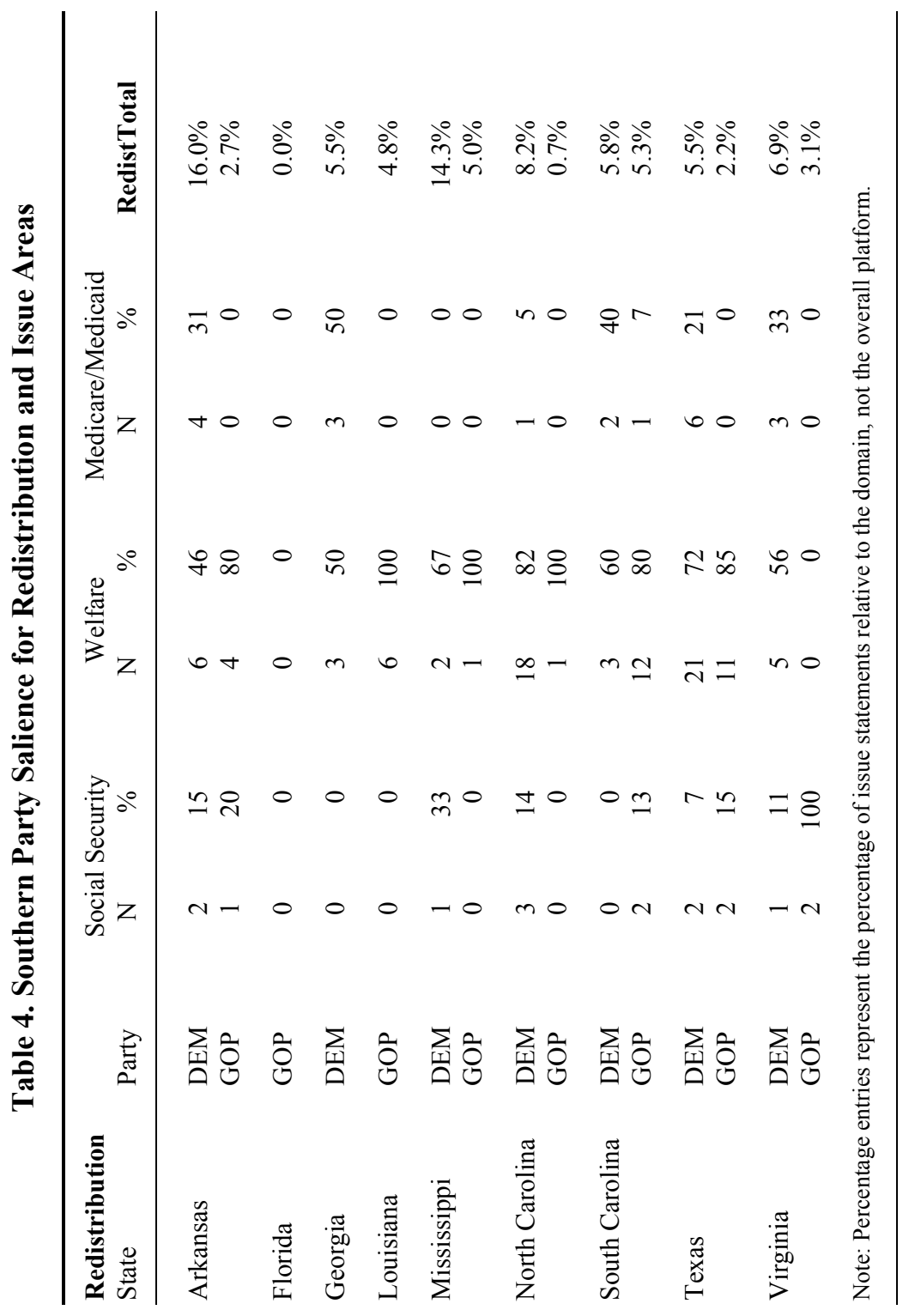


Variations of Issue Salience in Southern Parties | 261

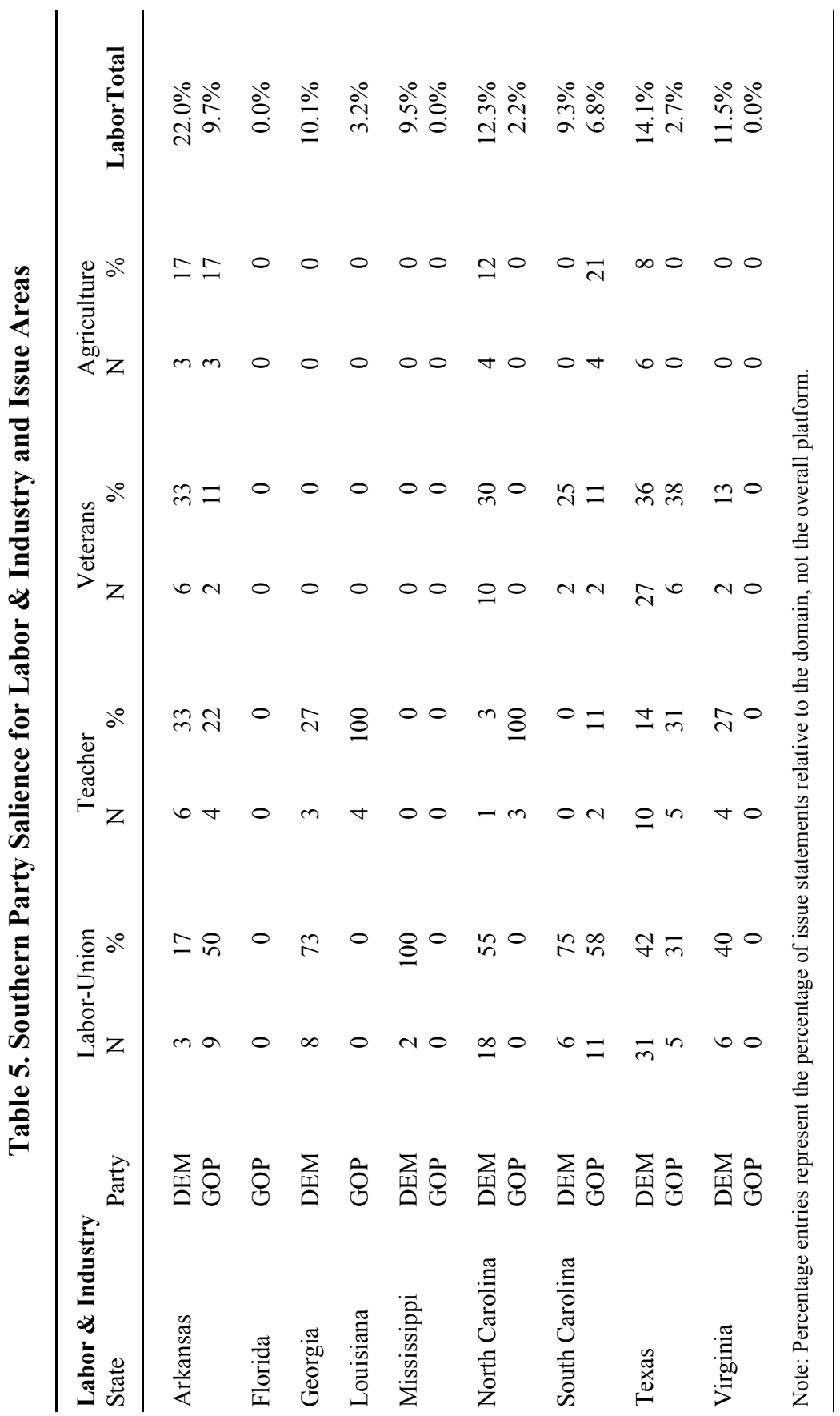


FL and VA Republicans - made no statements within the domain. For the remaining platforms, salience ranged from 4.2 percent $(\mathrm{SC}-\mathrm{R})$ to 15.1 percent (SC-D). Table 6 details the variance within the domain. Among the issue areas, Minority was the most salient overall (32\% mean for domain statements), and particularly for both parties in Arkansas, as well as for the Louisiana Republicans and Virginia Democrats. The issue of open government was the most salient for the North Carolina GOP, as well as Democratic platforms in South Carolina and Texas. Salience results for tort reform and access to courts were lower than other issues, and no real patterns emerged by party or state. The issue was most salient for Mississippi Republicans, whose one issue statement served as the only contribution toward the whole domain. Salience levels for election reform were generally higher than for tort reform, but were erratic and only emerged for both parties in the Carolinas and Texas.

\section{Law \& Order}

The Law \& Order domain proved to be salient in all southern party platforms. The mean salience for all parties was 15.8 percent. The domain yielded the highest salience level for Virginia Republicans, with 29.7 percent of all platform statements dedicated to this domain, while the lowest salience level is found in the Mississippi Democratic platform, with only 4.8 percent of platform statements. Among Democratic platforms the issue was most salient for Georgia (19.3\%). Among Republican platforms the domain salience levels were highest for Virginia (29.7\%) and Arkansas (29.0\%), and were least salient for Mississippi (10.0\%). The domain proved to be consistently more salient for Republicans than Democrats at a ratio nearing almost two to one. ${ }^{15}$

Within the domain, issues of criminal justice proved to be most salient among the issues and for all but four party platforms (see Table 7). The issue made consisted of an average of 48 percent of all domain statements. However, immigration also proved to be salient in every state but Florida (Republicans) and Mississippi, which issued no immigration statements. ${ }^{16}$ Salience levels for immigration were highest for South Carolina Democrats and lowest for North Carolina Democrats (among those platforms with statements). The issue area of gun control/Second Amendment also proved salient for both parties. The issue was most salient for Mississippi Democrats (but not for their Republican counterpart), whose only Law \& Order statement addressed the right to bear arms. This issue was also salient for Virginia Democrats (31\% of domain statements). Georgia and Texas Democrats made no statements on the issue. For Republicans, the issue proved to be most salient to Virginia (16\%). 


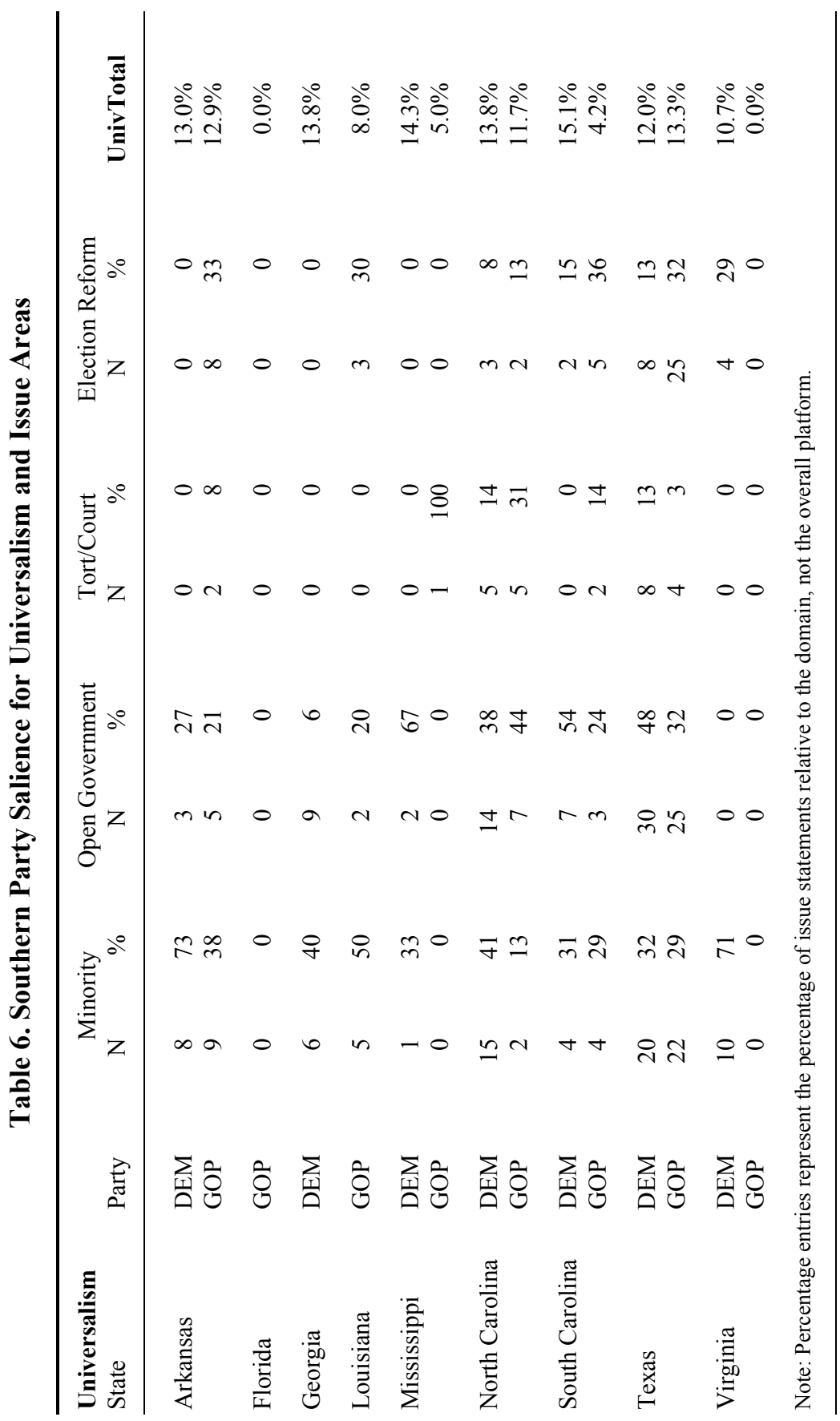


The two issue areas within Law \& Order ranking the lowest in terms of salience were those dealing with court systems and ethics. Few Democrats issued statements regarding the court systems in their state; the issue did prove to be more salient for Republicans, though percentages failed to break 10 percent for any platform. Ethics were most salient for the GOP as a whole, such as North Carolina and (to a lesser extent) Louisiana, but generally were not salient for either party.

\section{Foreign/Defense}

This domain exhibited low levels of overall salience, though not as low as the Internal Sovereignty domain. The mean salience level was 4.3 percent. Florida Republicans and Mississippi Democrats issued no statements for the domain, while the domain was the most salient for Texas Republicans $(10.5 \%) .^{17}$ These low salience levels may reflect the role of states within federalism, with state parties less likely to comment over a policy area they have relatively little control over.

Within the domain, almost all policy statements are geared toward defense and the use of the military (see Table 8). In only two states, South Carolina and Texas, were statements issued regarding specific foreign policy actions involving individual nation-states. These were only cursory for the parties with the exception of Texas Republicans, who included a lengthy section of twenty-nine statements on foreign policy stances toward individual nations.

\section{Social Issues}

Salience levels varied widely for Social Issues, though the domain received statements in every southern state platform. Social Issues proved to be the most salient domain for Louisiana, North Carolina, and Texas Republicans, each of which devoted more statements to this domain than any other. The highest percentage of statements was found in the Florida GOP platform (42.8\%), though it was tied with Economy in this domain. Salience levels were lowest for South Carolina Democrats, who only devoted 4.7 percent of their platform to the domain. An obvious pattern emerges with regard to interparty salience. The mean salience level for GOP platforms is 27 percent, indicating over one in four platform statements deals with Social Issues. Democratic salience only reached a mean percentage of 7 percent for the domain. No Democratic platform devoted more than 10 percent of their platform to Social Issues, and only one Republican platform (AR) devoted less than 10 percent. 
Table 8. Southern Party Salience for Foreign/Defense and Issue Areas

\begin{tabular}{|c|c|c|c|c|c|c|}
\hline \multicolumn{2}{|c|}{ Foreign \& Defense } & \multicolumn{2}{|c|}{ Defense } & \multicolumn{2}{|c|}{ Foreign/Specific } & \multirow[b]{2}{*}{ For/DefTota } \\
\hline State & Party & $\mathrm{N}$ & $\%$ & $\mathrm{~N}$ & $\%$ & \\
\hline \multirow[t]{2}{*}{ Arkansas } & DEM & 2 & 100 & 0 & 0 & $2.0 \%$ \\
\hline & GOP & 1 & 100 & 0 & 0 & $0.5 \%$ \\
\hline Florida & GOP & 0 & 0 & 0 & 0 & $0.0 \%$ \\
\hline Georgia & DEM & 7 & 100 & 0 & 0 & $6.4 \%$ \\
\hline Louisiana & GOP & 8 & 100 & 0 & 0 & $6.4 \%$ \\
\hline \multirow[t]{2}{*}{ Mississippi } & DEM & 0 & 0 & 0 & 0 & $0.0 \%$ \\
\hline & GOP & 1 & 100 & 0 & 0 & $5.0 \%$ \\
\hline \multirow[t]{2}{*}{ North Carolina } & DEM & 12 & 100 & 0 & 0 & $4.4 \%$ \\
\hline & GOP & 8 & 100 & 0 & 0 & $5.8 \%$ \\
\hline \multirow[t]{2}{*}{ South Carolina } & DEM & 4 & 80 & 1 & 20 & $5.8 \%$ \\
\hline & GOP & 9 & 82 & 2 & 18 & $3.9 \%$ \\
\hline \multirow[t]{2}{*}{ Texas } & DEM & 27 & 82 & 6 & 18 & $6.3 \%$ \\
\hline & GOP & 32 & 52 & 29 & 48 & $10.5 \%$ \\
\hline \multirow[t]{2}{*}{ Virginia } & DEM & 3 & 100 & 0 & 0 & $2.3 \%$ \\
\hline & GOP & 3 & 100 & 0 & 0 & $4.7 \%$ \\
\hline
\end{tabular}

Note: Percentage entries represent the percentage of issue statements relative to the domain, not the overall platform.

When examining the issue areas within the domain presented in Table 9 , salience levels are fairly evenly distributed. Only one platform devoted all domain statements to one issue. Mississippi Republicans issued all seven statements within the domain to the issues of life (abortion and stem cell). This issue was salient in all southern platforms, ranging from only one statement in three platforms (AR, MS, and VA Democrats, respectively), to fiftyone statements issued in the Texas Republican platform (39\% of all domain statements). This issue area was least salient for Virginia Democrats (8\%).

Religion, parent/family issues, and gay rights reflected variance in salience levels. Issues dealing with the role of religion in the public square were salient in only four Democratic platforms (GA, SC, TX, VA), but achieved some level of salience for all GOP platforms except Mississippi. This issue was most salient for Virginia Republicans (57\%). Issues dealing 
Variations of Issue Salience in Southern Parties | 267

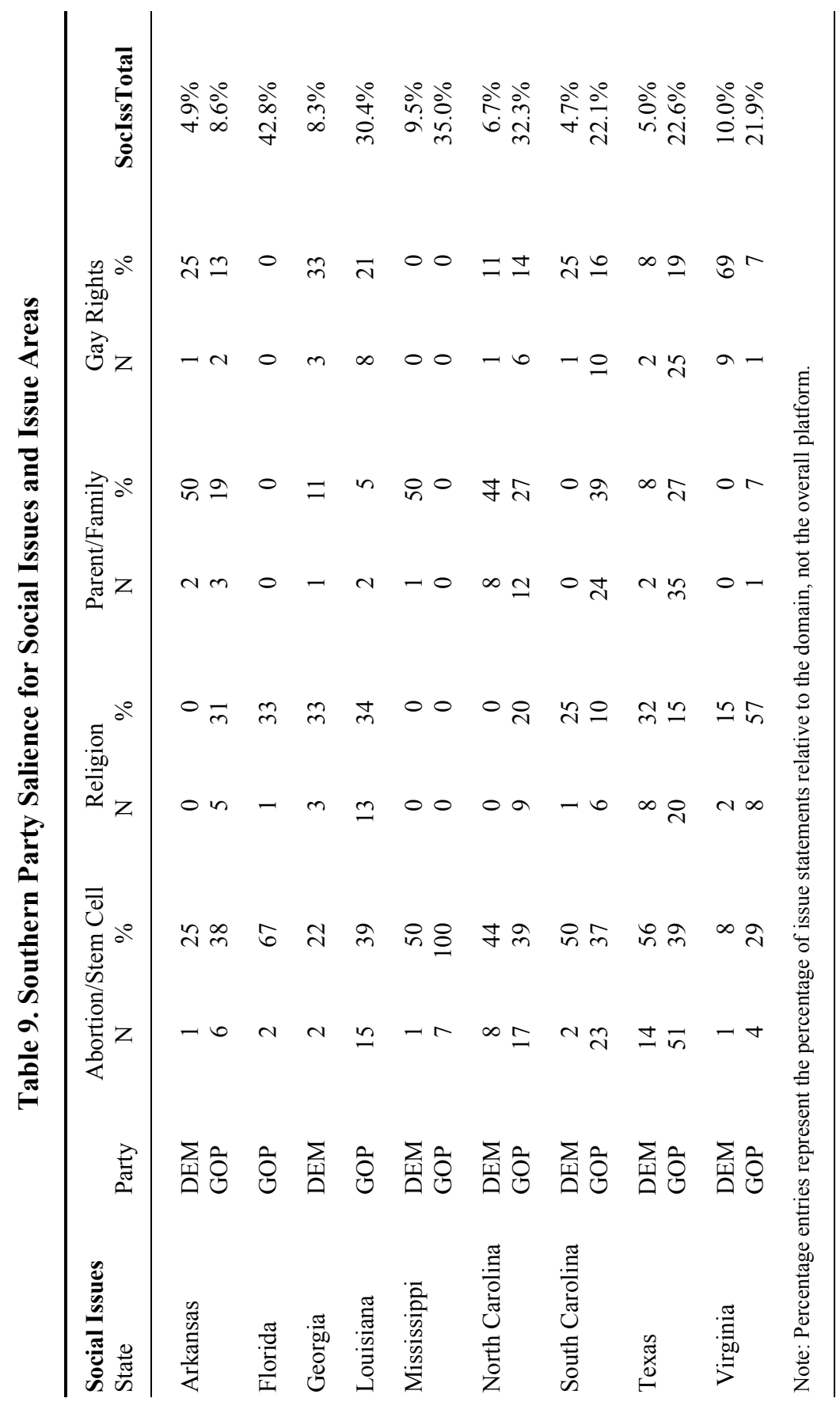


with parental rights and preserving the family ranged in salience from 0 percent (FL, MS Republicans, and SC and VA Democrats) to 50 percent of all domain statements in both the Arkansas and Mississippi Democratic platforms. The issue of gay rights was salient, but not as much as abortion/stem cell. Gay rights only dominated one platform-Virginia Democrats - where 69 percent of all domain statements dealt with this issue.

\section{Discussion}

What explains issue salience among the southern parties? At a basic level, the summary findings confirm both issue salience/ownership theories, as well as a traditional Downsian model. It is evident that policy priorities are shared by both parties within a local political environment. Thus, parties are forced to compete within the same electoral sphere, consistent with Downs' approach. It is impossible to assess intra-state party competition for Louisiana, Georgia, and Florida, for which only one platform is available per state. However, the remaining states can shed light on state policy priorities.

First, the variations in salience are evidence that parties respond to issues unique to the local political environment (Milkis 1999; Schattschneider 1942). Jacoby and Schnieder (2001) found that political factors within the states are the primary influence on each state's policy priorities. For instance, the authors found that states in the South and West have policy outputs that are focused on collective public goods such as highways, parks, education, and natural resources. These findings are consistent with salience levels in southern party platforms. While issues of property rights and natural resources do not appear as salient for southern parties (as opposed to those in the West), southern platforms do reflect education and public safety (criminal justice issues, Law \& Order domain) as salient issue areas.

On the whole, the Economy domain serves as a policy priority for all states (see Table 2). Domain salience levels are almost identical for both parties in Arkansas (30\% and $30.1 \%$, respectively) and are also close in Virginia as well. Within the domain, salience levels are also compatible in the individual issue areas. Environmental/energy issue salience levels are similar for both parties in Arkansas, Mississippi, South Carolina, and Texas, suggesting this issue area is salient enough for both parties to engage in some level of direct competition. Education also serves as a competitive issue area in Texas and Virginia. Salience levels for healthcare also suggest direct confrontation in Mississippi and Texas.

The limited salience for healthcare may suggest two possibilities. One option is that while the issue may be salient in the minds of the electorate, neither party has a strong enough policy preference/solution to address the issue to the electorate. Thus, they are less likely to fully engage to compete 
for electoral favor. From an issue ownership/salience theory perspective, one might point to this limited salience as proof that because neither side has claimed the issue as its own; both parties are reluctant to fully engage on the issue.

Another policy domain which may indicate interparty competition is Universalism. Domain salience levels were compatible for Arkansas, North Carolina, and Texas. However, this congruence diminishes when examining the individual issues. Texas and South Carolina do reveal direct party competition over issues of women and minority rights, but no other issues emerge as electoral battlegrounds.

The Law \& Order domain totals did not seem to indicate similar interparty salience levels, but patterns did emerge within the individual issue areas (see Table 7). This is reflected in Arkansas and South Carolina. Criminal justice was salient for both parties in these two states. Immigration also served to be a salient issue for Arkansans, while gun rights were salient in South Carolina. Texas and North Carolina also indicated similar salience levels on ethics (TX) and court systems (NC), but these levels were low.

Other individual issue areas emerged as salient for both parties. Agriculture and farming were salient for both parties in Arkansas (17\% each), reflecting the heavy dependence on agriculture in the Arkansas economy. Veterans' care was salient for both parties in Texas. Both abortion and gay rights salience levels were competitive in North Carolina.

\section{Owning the Issues}

If all politics is local and state party policy preferences simply respond to those conditions, then the platforms of both parties for each state should address the same set of issues. However, we know through this examination this is not the case. Salience levels for domains, and especially issue areas, suggest some level of issue ownership. According to Petrocik (1981), Republicans "own" Social Issues, national security and defense, and Economy issues referring to deregulation and fiscal discipline. Democrats are trusted to handle Universalism, Labor \& Industry, Redistribution, and special populations. Although Republicans are trusted with issues of national security and defense over Democrats, the overall assessment of foreign policy is based solely on performance rather than constituency influence. This is also the case for Economy in general and overall administration.

This study confirms that southern parties do follow patterns of emphasis on policy areas and individual issues. Republicans tend to focus on Social Issues, Internal Sovereignty, and Law \& Order over Democrats. Democrats clearly devote greater attention to Redistribution, Universalism, and Labor \& Industry than do Republicans. Even within domains, issue 
emphasis differs by party. For instance, immigration is more salient in Republican platforms than for Democrats within the Law \& Order domain.

\section{Republican Ownership}

Republicans clearly dominate the discussion regarding Social Issues, devoting almost four times as much emphasis on the domain as Democrats (see Table 9). Among the issues within the domain, GOP dominance is clearly continued on the issue of religion in the public square. Despite the overall domain ownership by Republicans, Democratic salience levels were competitive on the issue of gay rights, and to a lesser extent, abortion and stem cell. This indicates Democrats may be willing to engage on these issues. The issue of family life does not indicate any clear ownership as determined by percentage of statements issued. However, a clear trend emerges when reading the individual policy statements. Republican statements in the issue area are tightly focused on issues of parental rights over minors' health and school services (sex education, school clinics, etc.). Democrats, on the other hand, tended to issue policy statements regarding a holistic approach toward family life in general. Therefore, each party focuses on a different aspect of the issue area. Most statements do not address the same policy issues, thus confirming Budge and Farlie's (1983) assertion that parties tend to "talk past" one another.

Law \& Order domain results partially confirm Petrocik's (1981) assignment of policy areas to Republicans. This is especially true for immigration. However, other issue area salience levels reveal this is not absolute (see Table 7). The issue of criminal justice was only more salient for the GOP than Democrats in half of the state-level comparisons, and equal in South Carolina. Thus, Democrats are certainly willing to engage on the issue area. This is consistent with Parker's (2007) study of criminal justice within national platforms. Likewise, Democrats are willing to engage on the issue of gun rights and lead Republicans in terms of salience in Arkansas, Mississippi, and Virginia. This certainly calls in to question individual issue ownership for Republicans, despite domain scores.

Internal Sovereignty is also more salient for the GOP than Democrats. Republicans clearly command the issue of local autonomy, reinforcing the party's overall ideological perspective. However, Democrats were somewhat willing to engage on the issue, though in a limited manner. Some southern Democratic parties (SC, TX, and VA) were also willing to trespass on the issue of property rights. It is unclear if these parties were "forced" to engage as a result of the individual political environment of the state or not. It does not appear this is the case for Virginia, where the GOP made no statements concerning property rights. 


\section{Democratic Ownership}

Theories of issue salience/ownership are confirmed when examining interparty salience levels in the domains of Redistribution, Labor \& Industry, and Universalism. Democratic dominance is clear when examining the interparty results of Redistributive issues. Only in South Carolina are domain salience levels comparable. Democrats lead Republicans at a ratio of nearly three to one in this domain. ${ }^{18}$ Within the domain, overall statements on social welfare/safety net were the most salient, especially for the GOP (see Table 4). Only four GOP platforms made mention of specific welfare issues (Social Security and Medicare/Medicaid). These differences among the issue areas are due to the specificity of statements. GOP statements were generalized statements on the role of the welfare state as a whole, whereas Democratic platforms directed attention to specific welfare and redistributive programs. Again, this serves as some level of confirmation that parties will try to "talk past" each other (Budge and Farlie 1983). Republicans compete in an electoral arena where the welfare state is a burden, while Democrats will emphasize specific entitlement programs voters support. Neither is generally willing to engage the other in direct confrontation.

Labor \& Industry results also reinforce issue ownership for Democrats. However, these levels may not be as clear-cut when examining individual issues. This is similar to Republicans' ownership of Social Issues. For instance, Democrats clearly lead in salience levels for direct mention of laborunion issues. However, Republicans are willing to engage on issues of teacher rights and to a lesser extent, veterans and agriculture. Nevertheless, all Democrats included statements on the domain, in contrast to the two GOP platforms that did not. This suggests Republicans do not perceive any electoral advantages by engaging on these issues.

\section{Joint Custody?}

Although the Economy domain is salient for both parties and some issue areas suggest direct confrontation on the issues (such as healthcare and education), this is not universal. Republicans exhibit higher salience on the issue of public/private. However, Republicans tend to focus on the overall role of the government in private enterprise. These statements mainly address issues of taxation and regulation in general, consistent with Petrocik's (1981) assertion. In contrast, Democrats were more likely to mention specific initiatives on the other issue areas. Thus, do Republicans "own" public/private issues? Although Democrats will engage on these issues, the GOP will emphasize issues of taxation and regulation - areas they perceive as an electoral advantage — while Democrats stress education. 
Evidence of issue ownership also emerges even within seemingly competitive issue areas. This is especially true of environment/energy issues. While issue salience levels suggest direct confrontation in terms of policy preferences, this may not be the case. When examining individual statements, Republicans are more likely to give emphasis to energy over environment. Democrats tend to stress environmental protection as a primary issue, with environmentally-friendly or alternative energy sources as a supplemental emphasis. This suggests Republicans perceive an electoral advantage on energy, while Democrats' advantage is on environmentalism. Even when each party "trespasses" on the other's domain, it is done so gingerly with carefully selected language.

\section{Conclusion}

This examination of southern party platforms seeks to assess levels of issue salience. Historically, two approaches have been used to explain which issues parties emphasize. The results of this study reveal that issue salience/ ownership approach is well suited to explain one aspect of policy preferences, at least in the South. Each party emphasizes those issues that may contribute to electoral outcomes while downplaying those issues which may leave the party vulnerable. However, support for this approach is not absolute. While some issues are clearly dominated by one party, others seem to be fertile ground for interparty engagement and direct competition. Although it is beyond the scope of this study to explain the determinants of ownership or engagement, it is clear parties will continue to act to maximize electoral outcomes to win elections.

\section{NOTES}

${ }^{1}$ Coffey's (2006) case study of the Minnesota GOP reveals how evangelicals gained control of that party.

${ }^{2}$ Some state parties may rely on gubernatorial or other candidates to craft the party's platform, consistent with the modern candidate-centered partisan era. Still, other states may focus on an "action" or legislative agenda for highly specific policy issues, while relying on an overall philosophy, creed, or an "ongoing platform" for more general concerns.

${ }^{3}$ Some states, such as the Kentucky Democratic Party, may refer to the platform as an "agenda." In some instances, state parties will specify their policy positions through party "principles," "creeds," or "philosophy" statements or official party resolutions.

${ }^{4}$ Alabama and Tennessee currently have no official platforms. Alabama Republicans adopt the RNC platform as their own. Alabama Democrats historically draft an official platform annually; however, no official party plank has been adopted since 2006. That document is considered beyond the scope of this study. Tennessee Democrats adopts the statements of the DNC platform. Tennessee Republicans do issue a party 
"creed," but it does not contain definitive policy planks. Like the state's Democratic party, the Tennessee Republican Party officially adopts their national party's platform.

${ }^{5}$ Florida Republicans, Louisiana Republicans, and Georgia Democrats draft official documents; each of their counterparts in these states adopt their party's national platform.

${ }^{6}$ Both Ginsberg $(1972,1976)$ and Paddock $(1990,1992)$ use the paragraph as the unit of analysis within the platforms. While this method of analysis might be appropriate for lengthier documents expressing detailed information of implementation of each policy position such as a national platform, smaller policy documents characterized by brevity may express several policy arguments or endorsements within one paragraph.

${ }^{7}$ Therefore, taking the argument for a political idea as the coding unit of analysis may reflect a full sentence or a quasi-sentence. The two are not mutually exclusive. Not all quasi-sentences will encapsulate the full policy position, therefore leaving the complete sentence as the coding unit. Likewise, a complete sentence may have more than one policy position and will therefore be further separated into quasi-sentences.

${ }^{8}$ In an examination of all state platforms in the U.S., only one platform (in Colorado) asserted which issues are most salient, listing them in order of importance.

${ }^{9}$ While most issues of taxation and budgetary issues are coded within the "economy" domain, the estate/death tax is classified as "redistributive." While revenues from such a tax may be expended on programs other than those associated with a social safety net, the tax is progressive in nature, specifically targeted at the affluent as the base for redistribution.

${ }^{10}$ Only statements specifically addressing the redistribution of material or economic benefits are included.

${ }^{11}$ Issues involving members and veterans of the armed services pose some level of difficulty in terms of classification. Although placing these issues in the Foreign/Defense domain is appealing, such a classification would be inappropriate. The attitudes expressed toward determining appropriate levels of material benefits for servicemen, veterans, and family members may or may not be compatible with those attitudes toward the use of diplomacy toward foreign states. Because the provision of benefits crosses both sectors of civilian and military personnel administration, these are grouped together within this domain. Like those issues addressed in the Redistribution domain, statements in this domain only refer to material and economic benefits rather than civil rights.

${ }^{12}$ Florida Republicans issued no statements on environmental/energy issues.

${ }^{13}$ Two GOP platforms made no statements on healthcare. When measuring salience levels among only GOP platforms containing healthcare statements, the mean percentage rises to $15.2 \%$.

${ }^{14}$ Discussion of Native American and Territorial Issues are omitted here. The category was included to accommodate the platforms of both Texas parties. Issue statements only totaled 3 across the board.

${ }^{15}$ The mean domain salience for Democrats was $11.3 \%$, while GOP domain mean salience was $19.8 \%$.

${ }^{16}$ While at first glance the omission of the immigration issue in Florida appears odd, it is most likely due to the low number of overall platform statements $(\mathrm{N}=7)$. This is not to suggest immigration is not a salient issue in Florida politics; nevertheless, it is a distinction that the Florida GOP had no statements in this issue area.

${ }^{17}$ Again, low salience levels are most likely due to the low numbers of overall platform statements for these two parties.

${ }^{18}$ Democrats' salience mean was $8.9 \%$ compared to Republicans' $3 \%$. 


\section{REFERENCES}

Aldrich, John H. 1995. Why Parties? The Origin and Transformation of Political Parties in America. Chicago: University of Chicago Press.

Bridgmon, Shannon L. 2009. One Big Party? An Assessment of State and National Ideological Unity. Ph.D. dissertation, University of Alabama.

Budge, Ian, and Dennis J. Farlie. 1977. Voting and Party Competition. London: Wiley.

Budge, Ian, and Dennis J. Farlie. 1983. Explaining and Predicting Elections: Issue Effects and Party Strategies in Twenty-Three Democracies. London: George Allen $\&$ Unwin (Publishers) Ltd.

Budge, Ian, and Hans-Dieter Klingemann, et al. 2001. Mapping Policy Preferences: Estimates for Parties, Electors, and Governments, 1945-1998. Oxford, UK: Oxford University Press.

Clifton, Brett M. 2004. Romancing the GOP: Assessing the Strategies Used by the Christian Coalition to Influence the Republican Party. Party Politics 10(5):475-498.

Coffey, Daniel J. 2005. State Party Organization and State Party Ideology. Presented at the 2005 State Politics and Policy Conference, East Lansing, MI.

Coffey, Daniel J. 2006. State Party Agendas: Representation in an Era of Polarized Parties. Ph.D. dissertation, University of Virginia.

Cotter, Cornelius, James Gibson, John Bibby, and Robert Huckshort. 1984. Party Organizations in American Politics. New York: Praeger.

Dellis, Arnaud. 2009. The Salient Issue of Issue Salience. Journal of Public Economic Theory 11(2):203-231.

Damore, David F. 2004. The Dynamics of Issue Ownership in Presidential Campaigns. Political Research Quarterly 57(3):391-397.

Downs, Anthony. 1957. An Economic Theory of Democracy. New York: Harper and Brothers.

Elling, Richard C. 1979. State Party Platforms and State Legislative Performance: A Comparative Analysis. American Journal of Political Science 23(2):383-405.

Fishel, Jeff. 1985. Presidents and Promises. Washington, DC: Congressional Quarterly Press.

Gimpel, James A., and Jason E. Schuknecht. 2003. Patchwork Nation: Sectionalism and Political Change in American Politics. Ann Arbor: University of Michigan Press.

Ginsberg, Benjamin. 1972. Critical Elections and the Substance of Party Conflict, 18441968. Midwest Journal of Political Science 16(November):603-626.

Ginsberg, Benjamin. 1976. Elections and Public Policy. American Political Science Review 70:41-49.

Jacoby, William G., and Saundra K. Schneider. 2001. Variability in State Policy Priorities: An Empirical Analysis. Journal of Politics 63(2):544-568.

Key, V.O. 1949. Southern Politics in State and Nation. New York: Random House.

Laver, Michael, and John Garry. 2000. Estimating Policy Positions from Political Texts. American Journal of Political Science 44(3):619-634.

Libbrecht, Liselotte, Bart Maddens, Wilfried Swenden, and Elodie Fabre. 2009. Issue Salience in Regional Party Manifestos in Spain. European Journal of Political Research 48:58-79.

Milkis, Sidney J. 1999. Political Parties and Constitutional Government. Baltimore, MD: Johns Hopkins University Press.

Nie, Norman H., Sidney Verba, and John R. Petrocik. 1976. The Changing American Voter. Cambridge, MA: Harvard University Press. 
Paddock, Joel. 1990. Beyond the New Deal: Ideological Differences between Eleven State Democratic Parties, 1956-1980. Western Political Quarterly 43(March):181190.

Paddock, Joel. 1992. Inter-Party Ideological Differences in Eleven State Parties: 19561980. Western Political Quarterly 45(September):751-760.

Paddock, Joel. 1998. Explaining State Variation in Interparty Ideological Differences. Political Research Quarterly 51:765-780.

Paddock, Joel. 2005. State and National Parties and American Democracy. New York: Peter Lang Publishing, Inc.

Pagorelis, Robertas, Bart Maddens, Wilfried Swenden, and Elodie Fabre. 2005. Issue Salience in Regional and National Party Manifestos in the U.K. West European Politics 28(5):992-1014.

Parker, Paul. 2007. Partners in Crime? Issue Ownership Reconsidered. Presented at the 2007 Midwest Political Science Association Meeting, Chicago, IL.

Petrocik, John R. 1981. Realignments and the Decline of the New Deal Party System. Chicago and London: University of Chicago Press.

Petrocik, John R. 1996. Issue Ownership in Presidential Elections, with a 1980 Case Study. American Journal of Political Science 40(3):825-850.

Pomper, Gerald. 1980. Party Renewal in America: Theory and Practice. New York: Praeger.

Pomper, Gerald. 2003. Parliamentary Government in the United States: A New Regime for a New Century? In The State of the Parties: The Changing Role of Contemporary Parties, 4th ed., eds. John C. Green and Robert Farmer. New York: Rowan and Littlefield.

Rabinowitz, George, and Stuart Elaine Macdonald. 1989. A Directional Theory of Issue Voting. American Political Science Review 83(1):93-121.

Rallings, Colin. 1987. The Influence of Election Programmes: Britain and Canada 19451979. In Ideology, Strategy, and Party Change, ed. Ian Budge, David Robertson, and Derek Hearl. London: Cambridge University Press.

Royed, Terry J. 1996. Testing the Mandate Model in Britain and the United States. British Journal of Political Science 26:45-80.

Schattschneider, E.E. 1942. Party Government. New York: Farrar and Rinehart, Inc.

Sigelman, Lee, and Emmett H. Buell, Jr. 2004. Avoidance or Engagement? Issue Convergence in U.S. Presidential Campaigns, 1960-2000. American Journal of Political Science 48(4):650-661. 